question to the editor of the Medical Times and Hospital Gazette as a fair record of the proceedings.

I am, Sirs, yours faithfully

Lavender-hill, S.W., Oct. 27th, 1896.

R. H. BARKWELL.

** We have received a letter to the same effect from the editors of the Medical Times and Hospital Gazette.-ED. L.

\section{"THE SWISS NATIONAL EXHIBITION AT GENEVA."}

To the Editurs of THE LANCET.

SIRS,-My attention has been called to-day to an annotation in THE LANCET of April 25th last in which occurs the following:- "A box or case is placed round the body in the region of the stomach and liver, a handle is turned, and liquid air is pumped in through the pores of the skin." Being one of the two physicians who conduct this therapeutic means (Dr. Chassat is the other one), I cannot let pass unnoticed such a mistake. The fact is that a cylinder 65 centimetres wide and 1.80 metres deep, furnished with a double envelope, is cooled to $-166^{\circ} \mathrm{F}$. $\left(110^{\circ} \mathrm{C}\right.$.). It is lined with a fur. The patient descends into that well, and remains from ten to twenty minutes. His shoulders are covered with a rug, to prevent him from breathing the cold air, and for preventing the warm air from penetrating into the well. His temperature generally rises about $1^{\circ} \mathrm{F}$. (from $0.2^{\circ}$ to $08^{\circ} \mathrm{C}$.). This treatment is used especially in nervous diseases of the stomach with fair success. We are waiting for occasions of trying it in other diseases with lowering of the nutrition (diabetes, obesity, anæmia, \&c.)

Preparing for the Gynæcological Congress (of which I am secretary-general), I cannot now spare time to give you a long article; but I can refer you to the Journal de Médecine de Paris, July 26th and also Aug. 9th, 1896. The third article of mine in the same journal is not yet published. An article from Dr. Chassat's pen will appear in the next edition of Médecine Hypodermique. The liquid air is made in another part of the Pavillon Raoul Pictet. It requires a temperature of $-371^{\circ} \mathrm{F} .\left(-219^{\circ} \mathrm{C}.\right)$. - I am, Sire, yours faitbfully,

Geneva, Aug. 25th, 1896.

A. Condes.

** The words quoted by our correspondent do occur, but we mentioned that we had only seen a description of the apparatus, not the apparatus itself.-ED. L.

\section{"POISONOUS HONEY."}

\section{To the Editors of THE LANCET.}

SrRs,-I have read with interest some remarks on "poisonous honey" in recent impressions of THE LANCET. I believe symptoms of poisoning after having eaten boney occur more frequently than maby people are aware of. A gentleman a fortnight ago had a small quantity of honey sent to him in consequence of its having come from the north of Scotland. The honey was red in colour, thick in consistence, and not very agreeable in taste and odour, but these peculiarities were attributed to the heather from which the bees had gathered the horey. A small quantity was eaten by the recipient of the present, who was in very good health at the time, but coincidently with his partaking of the honey disagreeable symptoms set in. They were nausea, flatulence, severe headache, heat of head, drowsiness, and great dizziness. These symptoms slowly passed away when eating of the honey was not repeated but even now the gentleman has not regained his usual equilibrium when walking, and his normal power of diges. tion. It is most probable in this case that the little busy bees who gathered the honey picked up and introduced into it some deleterious ingredient, harmless no doubt to themselves, but poisonous to man. It is generally supposed that the best honey is gathered from heather, for the famous honey of Hymettus was taken from the heath plant.

I remember having seen symptoms of poisoning in a schoolboy caused by eating the honey of the wild bee (Bombus). Many people cannot eat the delicious and fragrant honey of the humble bee without suffering from headache and dizziness. It is said that honey collected from some particular flowers in Jersey is unfit for use in consequence of its poisonous properties. But for honey poisoning on a large scale we must go back to the celebrated "Retreat of the 'Ten Thousand." which occurred about 401 years B.C. After the battle of Cunaxa and the death of
Cyrus the famous retreat of the ten thousand Greeks began under the conduct of the great Xenophon, and after numerous feats of valour and untold hardships the troops reached the Colchian Mountains. Here the soldiers, finding plenty of honey of exquisite taste and flavour, ate large quantities of it. After eating they were soon seized with severe giddiness. Those who had eaten little conducted themselves like drunken men and those who had eaten much were attacked with a kind of frenzy, so that the ground round the camp presented the appearance of a field of battle covered apparently with dying men. In about twenty-four hours, bowever, they recovered their senses. The dangerous symptoms generally vented themselves in violent vomiting and purging, which weakened the soldiers so much that it was only after several days that they could stand on their feet. Having at length recovered their strength the Greeks proceeded to Trebizond, which they reached after a march of three days. I think it was this incident in the "Retreat of the Ten Thousand" that Thomas Moore had in view when he wrote the lines in "Lalla Rooke"-

Er'n as those bees of Trebizond, Which from the sunniest flowers that glad With their pure smile the gardens round Draw venom forth that drives men mad!"

$$
\text { I am, Sirs, yours truly, }
$$

William O'NEILL, M.D. Aberd., M.R.C.P. Lond Lincoln, Oct. 20tb, 1890.

\section{"THE NEW HOSPITAL FOR WOMEN, EUSTON-ROAD, AND GENERAI PRACTITIONERS." \\ To the Editors of THE LANCET.}

SiRs, - I beg to call your attention to a clerical error in The LANCET of Oct. 17th. On page 1113, in my letter of Oct. 8th to Dr. McLaurin, you have printed, "A small payment is required from every patient and goes to the funeral fund of the hospital." Kindly alter it to "general fund," as it stood in my letter. A funeral fund does not, I am thankful to say, exist, nor is it required.

Oct. 16th, 1896.

I am, Sirs, faithfully yours,

HELEN WEBB

** In the type-written MS. of the correspondence in question the word was clearly "funeral" and not "general." We regret the error, but we could not guess that it was there. The sen:e was good, and the names of some of the off-shoots of large charities are often curious.-ED. L.

\section{"HOSPITAL REFORM."}

\section{To the Editors of THE LANCET.}

SIRS,-As you well remarked in your annotation in THE LANCET of Oct. 24th the subject of Hospital Reform teems with difficulties. It is only reasonable, therefore, that an association which is barely a month old should be allowed a fair amount of time to consider its bearings before taking any decisive action. I may, however, be allowed to state that the association has not been idle. It has placed itself in communication with the branches of the Charity Organisation Society in most of the big towns, and it has sought the coöperation of many of the branches of the British Medical Association. Moreover, it has practically decided to recommend the hospital authorities to adopt the following plans for the prevention of the $a b u s e$ and of the overcrowding of the out-patient departments - viz., (1) the appointment of a properly qualified person to make inquiries into the circumstances of patients after they have received first aid; and (2) the strict limitation of the number of $n \in w$ cases to be seen by each medical officer.

The association is aware that enquiries are now made at some of the hospitals, but with one or two exceptions such enquiries are made either by one of the resident medical staff or by the secretary. It is felt that in all the large hospitals these officials have not sufficient time at their disposal to make a thorough investigation. With regard to special hospitals, the association would feel gratified to members of the profession if they would kindly place any information they may possess in the hands of the honorary secretary. It will probably be found necessary to appoint a sub-committee to thoroughly investigate the conditions relating to such institutions. In conclusion, perhaps you will permit me to appeal to the profession generally to help 